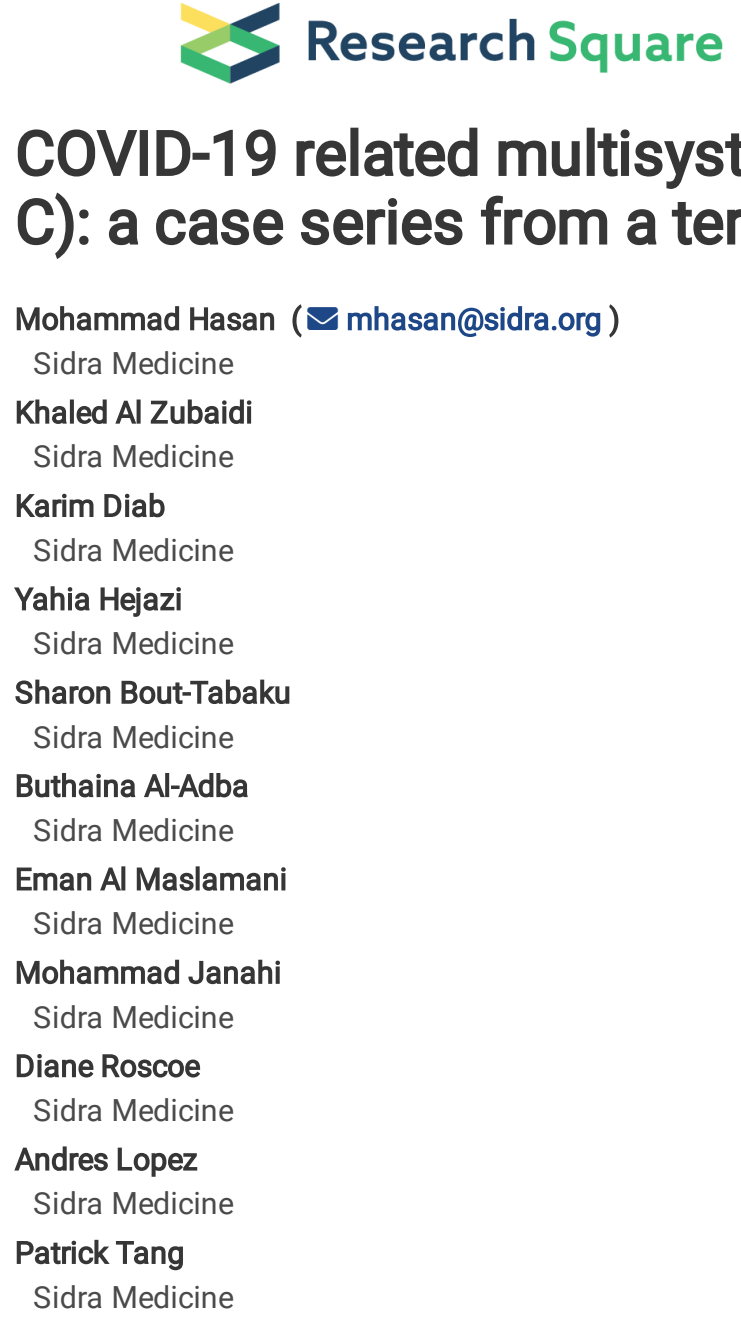

\title{
COVID-19 related multisystem inflammatory syndrome in children (MIS- C): a case series from a tertiary care pediatric hospital in Qatar
}




\section{Abstract}

Background: Multisystem Inflammatory Syndrome in Children (MIS-C) is a severe complication of coronavirus disease 2019 (COVID-19) in children, which is increasingly being reported worldwide. Here we report the first case series of 7 children diagnosed with MIS-C in Qatar.

Methods: Clinical features and outcomes of COVID-19 positive patients admitted to Sidra Medicine, Qatar from June to October 2020, who met the WHO case definition for MIS-C were reviewed.

Results: The mean age in our case series was 5.6 years, of which $71.4 \%$ were males. All patients were previously healthy but had a history of COVID-19 infection. Fever, rash, vomiting and abdominal pain were the most common symptoms (70\%-100\%). The average hospitalization was 12.9 days with no case fatalities. Laboratory findings included lymphopenia and thrombocytopenia in most patients, as well as evidence of coagulopathy and elevated inflammatory markers such as C-reactive protein, ferritin and procalcitonin. Many patients (71.4\%) required inotropic support in intensive care, while only one required respiratory support. Although all patients had elevated cardiac biomarkers, cardiovascular involvement was observed in $42.9 \%$ of patients with one patient developing a giant coronary aneurysm. All patients received intravenous immunoglobulin (IVIG) and $86 \%$ of patients received corticosteroids, with two patients requiring treatment with IL-1 inhibitors.

Conclusions: Our report is one of the first reports on MIS-C from Asia. Although clinical features and outcomes are not significantly different from those reported elsewhere, lack of case fatalities in our cohort may indicate that early recognition and prompt medical attention is necessary for a favorable outcome in MIS-C.

\section{Background}

The pandemic of coronavirus disease 2019 (Covid-19) caused by severe acute respiratory syndrome coronavirus 2 (SARS-CoV-2) has had a catastrophic effect on the human population with approximately $20 \%$ of infected persons experiencing severe or critical disease, and an overall case fatality rate of 2.3\%.[1] Although most children with COVID-19 have mild symptoms or have no symptoms at all, some children become severely ill needing hospitalization, intensive care, or ventilatory support. Multisystem Inflammatory Syndrome in Children (MIS-C) is a rare but serious medical condition associated with COVID-19.[2] MIS-C is defined by inflammation in different organs such as the heart, kidneys, lungs, brain, skin, eyes, or gastrointestinal system. The causes of MIS-C remain unknown but it has been associated with SARS-CoV-2 infection.[3] Approximately $40-50 \%$ of children with MIS-C meet criteria for complete or incomplete Kawasaki disease (KD). The clinical presentation of MISC may also resemble that of toxic shock syndrome (TSS), secondary hemophagocytic lymphohistiocytosis, or macrophage activation syndrome. [4] The true incidence of MIS-C is still uncertain but an estimated incidence of $0.6 \%$ among laboratory confirmed COVID-19 patients has been reported in New York.[5]

To date, the majority of MIS-C cases have been reported from North America and European countries with very few reports from Asian countries [4-9]. Large case series conducted in the USA and UK show that risks associated with developing MIS-C may vary by gender, age and ethnicity. Although male gender and black and Hispanic races were predominantly affected [4-6], it is possible that MIS-C among Asians are underrepresented because of under reporting. In this study, we aim to review and summarize the clinical presentation, laboratory parameters, outcome and management of MIS-C cases presenting to a tertiary care pediatric hospital in Qatar and compare them with previously published cases in other countries.

\section{Methods}

Sidra Medicine is a 400-bed women's and children's tertiary care hospital in Qatar. MIS-C cases were identified by querying in the electronic medical record of children with COVID-19. Probable cases brought to the attention of infectious disease physicians and medical microbiologists were also included. Only patients who met the World Health Organization (WHO) case definition of MIS-C were selected for chart-review. Data were recorded in a standardized form and deidentified. Descriptive statistics were performed and presented as mean and standard deviation $( \pm / S D)$ for continuous variables or as number and percentages for nominal/categorical variables.

\section{Results}

At the time of this report, there were approximately 138,000 COVID-19 cases and 237 associated deaths reported in Qatar. Since the initiation of COVID-19 screening at Sidra Medicine (April 16 to Nov. 21, 2020), a total of 28,653 COVID-19 tests were performed of which 7,812 were on individuals $<18$ years old. During this period, a total of 167 children were positive for COVID-19 by RT-qPCR, and 7 of these patients fulfilled the WHO criteria for MIS-C and were managed in our hospital. The mean age at diagnosis was $5.6 \pm 2.7$, and the majority of the cases were male $(71.4 \%)$ (Table 1). All patients were previously healthy. Five out of 7 cases were initially admitted to the pediatric intensive care unit (PICU), primarily for vascular support. 
Table 1

Patient characteristics and clinical presentation

\begin{tabular}{|c|c|c|c|c|c|c|c|c|}
\hline & Case-1 & Case-2 & Case-3 & Case-4 & Case-5 & Case-6 & Case-7 & Summary \\
\hline \multicolumn{9}{|l|}{ Demographics } \\
\hline Age & 6 & 6 & 3 & 7 & 7 & 9 & 1 & Mean, $5.6 \pm 2.7$ \\
\hline Gender & Male & Male & Male & Male & Female & Female & Male & Male, $71.4 \%$ \\
\hline \multicolumn{9}{|l|}{ Clinical presentation } \\
\hline Fever & Yes & Yes & Yes & Yes & Yes & Yes & Yes & $100 \%$ \\
\hline Rash & No & Yes & Yes & Yes & Yes & Yes & Yes & $85.7 \%$ \\
\hline Tachycardia & Yes & No & Yes & Yes & No & Yes & Yes & $71.4 \%$ \\
\hline Tachypnea & No & Yes & No & No & Yes & No & No & $28.6 \%$ \\
\hline Hypotension & Yes & Yes & No & Yes & No & No & No & $42.9 \%$ \\
\hline Abdominal pain & Yes & No & Yes & *Yes & Yes & Yes & No & $71.4 \%$ \\
\hline Diarrhea & No & No & Yes & No & No & Yes & Yes & $42.9 \%$ \\
\hline Vomiting & Yes & Yes & Yes & Yes & Yes & Yes & Yes & $100 \%$ \\
\hline Decreased oral intake & Yes & Yes & Yes & No & No & No & Yes & $57.1 \%$ \\
\hline Cough & Yes & No & No & No & No & No & No & $14.3 \%$ \\
\hline Sore throat & No & Yes & No & No & No & No & No & $14.3 \%$ \\
\hline Conjunctivitis & No & Yes & No & Yes & No & Yes & Yes & $57.1 \%$ \\
\hline
\end{tabular}

Fever and rash were the most common presenting symptoms among the MIS-C cases in our hospital with $100 \%$ and $85.7 \%$ of the patients experiencing these symptoms, respectively (Table 1). Additionally, gastrointestinal symptoms were common among these patients with $100 \%$, $71.4 \%$ and $42.9 \%$ patients presenting with vomiting, abdominal pain and loose stools, respectively. Upper respiratory tract infection (URTI) symptoms were less prevalent in our study group, with cough and sore throat experienced by one patient each, and conjunctivitis in 3 other patients. Two of the cases were suspected to have urinary tract infection (UTI) based on initial urine microscopy, however none had urinary tract symptoms at the time of presentation or had a positive urine culture after presentation.

Two of the cases had previous positive RT-qPCR results for SARS-CoV-2 (Table 2). At presentation, only case had positive nasopharyngeal swab (NPS) for SARS-CoV-2. Two of the remaining 4 cases were initially negative by RT-qPCR in NPS but were later found to have positive COVID-19 serology. Additional RT-qPCR testing for these patients using nasopharyngeal wash (NPW) specimens confirmed the presence of SARS-CoV-2 RNA. Of the 6 children who were tested for antibodies to SARS-CoV-2, all were positive. 
Table 2

Laboratory results

\begin{tabular}{|c|c|c|c|c|c|c|c|c|}
\hline & Case-1 & Case-2 & Case-3 & Case-4 & Case-5 & Case-6 & Case-7 & Summary \\
\hline \multicolumn{9}{|l|}{ COVID-19 } \\
\hline \multirow[t]{2}{*}{ RT-qPCR } & $\begin{array}{l}\text { NPS- } \\
\text { Neg }\end{array}$ & $\begin{array}{l}\text { NPS- } \\
\text { Neg }\end{array}$ & $\begin{array}{l}\text { NPS- } \\
\text { Pos }\end{array}$ & $\begin{array}{l}\text { NPS- } \\
\text { Neg }\end{array}$ & $\begin{array}{l}\text { *NPS- } \\
\text { Pos }\end{array}$ & $\begin{array}{l}\text { *NPS- } \\
\text { Pos }\end{array}$ & $\begin{array}{l}\text { NPS- } \\
\text { Neg }\end{array}$ & $\begin{array}{l}71.4 \% \text { cases positive in at least one } \\
\text { specimen }\end{array}$ \\
\hline & $\begin{array}{l}\text { NPW- } \\
\text { Pos }\end{array}$ & $\begin{array}{l}\text { NPW- } \\
\text { Pos }\end{array}$ & & & & & & \\
\hline Serology & Positive & Positive & Positive & Positive & $\begin{array}{l}\text { Not } \\
\text { done }\end{array}$ & Positive & Positive & $6 / 6,100 \%$ positive \\
\hline \multicolumn{9}{|l|}{ Hematology } \\
\hline \multirow[t]{2}{*}{ WBC $\left(10^{9} / \mathrm{L}\right)$} & 27.3 & 19.4 & 16 & 9.7 & 16.9 & 6.9 & 24.1 & $71.4 \%$ above range \\
\hline & & & & & & & & (Ref: 4-14) \\
\hline \multirow{2}{*}{$\begin{array}{l}\text { Neutrophil } \\
\left(10^{9} / \mathrm{L}\right)\end{array}$} & 24.4 & 16.5 & 5.3 & 9.5 & 13.9 & 4.6 & 16.1 & $71.4 \%$ above range \\
\hline & & & & & & & & (Ref: 0.8-7.2) \\
\hline \multirow{2}{*}{$\begin{array}{l}\text { Lymphocyte } \\
\left(10^{9} / \mathrm{L}\right)\end{array}$} & 0.9 & 0.8 & 1.2 & 0.2 & 2.1 & 0.6 & 6.5 & $71.4 \%$ below range \\
\hline & & & & & & & & (Ref: 1.3-8) \\
\hline \multirow{2}{*}{$\begin{array}{l}\text { Platelets } \\
\left(10^{3} / \mathrm{mL}\right)\end{array}$} & 140 & 80 & 570 & 105 & 116 & 105 & 900 & $71.4 \%$ below range \\
\hline & & & & & & & & (Ref: 150-400) \\
\hline \multicolumn{9}{|c|}{ Inflammatory markers } \\
\hline \multirow[t]{2}{*}{$\mathrm{CRP}(\mathrm{mg} / \mathrm{L})$} & 262.2 & 228.3 & 162 & 304.5 & 93 & 82.8 & 143 & $100 \%$ above range \\
\hline & & & & & & & & (Ref: 0-7.5) \\
\hline \multirow[t]{2}{*}{ Ferritin (ng/mL) } & 324 & 581 & 377 & 334 & 326 & 341 & 621 & $100 \%$ above range \\
\hline & & & & & & & & (Ref: 10-56) \\
\hline \multirow[t]{2}{*}{ PCT (ng/mL) } & 21.6 & 7.22 & 9.4 & $>50$ & 2.15 & Not & 0.59 & $6 / 6,100 \%$ above range \\
\hline & & & & & & & & (Ref: <0.1) \\
\hline \multirow[t]{2}{*}{ IL-6 (pg/mL) } & 35 & 4 & Not & Not & 2665 & Not & 100 & $3 / 4$ above range \\
\hline & & & & & & & & (Ref: 0-16.4) \\
\hline \multicolumn{9}{|l|}{ Coagulation } \\
\hline \multirow[t]{2}{*}{ PT (sec) } & 16.8 & 15.1 & 18.3 & 17 & 17.5 & 15.9 & 12 & $83 \%$ above range \\
\hline & & & & & & & & (Ref: 11.7-15.1) \\
\hline \multirow[t]{2}{*}{ D-dimer (mg/L) } & 7440 & 2266 & 7500 & $>7500$ & 3538 & 2381 & 3060 & $100 \%$ above range \\
\hline & & & & & & & & (Ref: $\leq 500)$ \\
\hline \multirow{2}{*}{$\begin{array}{l}\text { Fibrinogen } \\
(\mathrm{mg} / \mathrm{dL})\end{array}$} & 4 & 3.9 & 3.4 & 4.4 & 3.7 & 3.6 & 4.3 & $28.6 \%$ above range \\
\hline & & & & & & & & (Ref: 1.6-4) \\
\hline \multicolumn{9}{|l|}{ Cardiac } \\
\hline \multirow[t]{2}{*}{ Troponin (ng/L) } & 40 & 14 & 68 & 309 & 161 & 34 & 4 & $100 \%$ above range \\
\hline & & & & & & & & (Ref: 0-0.4) \\
\hline \multirow{2}{*}{$\begin{array}{l}\text { NT-proBNP } \\
(\mathrm{ng} / \mathrm{L})\end{array}$} & 5253 & 7006 & 2314 & 2874 & 592 & 506 & 1444 & $100 \%$ above range \\
\hline & & & & & & & & (Ref: <125) \\
\hline \multicolumn{9}{|c|}{$\begin{array}{l}\text { NPS, nasopharyngeal swab; NPW, nasopharyngeal wash; WBC, white blood cell; CRP, C-reactive protein; PCT, procalcitonin; PT, prothrombi } \\
\text { time; NT-proBNP, N-terminal B-type natriuretic peptide }\end{array}$} \\
\hline \multicolumn{9}{|l|}{ *Previous positive } \\
\hline
\end{tabular}


All patients had extensive laboratory workup done upon admission or at the time when MISC was suspected (Table 2). Although total white blood cell (WBC) counts were variable among our study population with a range between 6.9 to 27.3 (10 $/ \mathrm{L}), 5$ of 7 cases were lymphopenic for their age. Additionally, 5 cases had a low platelet count for their age, although none had severe thrombocytopenia. All of our MIS-C cases showed a hyperinflammatory status with remarkably high C-reactive protein (CRP), procalcitonin (PCT) and ferritin levels, and deranged coagulation profile. IL-6 was high in 3 of 4 cases who were tested during their hospital stay.

Chest radiography was performed on 6 of 7 patients (Table 3). The most commonly described abnormalities were bilateral perihilar infiltrates and peribronchial thickening. Bilateral interstitial opacities and pulmonary edema were described in just one patient. Abdominal ultrasound (US) was performed on 6 of 7 patients. The most significant finding was that of an aortic aneurysm in one patient. The remaining patients had a variety of non-specific findings including increased echogenicity of the liver, gall bladder wall edema and thickening, bulky and echogenic kidneys, enlarged mesenteric lymph nodes, pleural effusions and ascites.

Table 3

Clinical outcome

\begin{tabular}{|c|c|c|c|c|c|c|c|c|}
\hline & Case-1 & $\begin{array}{l}\text { Case- } \\
2\end{array}$ & $\begin{array}{l}\text { Case- } \\
3\end{array}$ & Case-4 & Case-5 & $\begin{array}{l}\text { Case- } \\
6\end{array}$ & Case-7 & Summary \\
\hline $\begin{array}{l}\text { Hospital length of } \\
\text { stay (days) }\end{array}$ & 12 & 10 & 6 & 20 & 7 & 8 & 27 & $\begin{array}{l}\text { Mean, } \\
12.9 \pm 7.8\end{array}$ \\
\hline ICU stay (days) & 12 & 10 & None & 11 & 4 & 3 & None & $71.4 \%$ \\
\hline Shock & Yes & Yes & None & Yes & None & Yes & None & $57.1 \%$ \\
\hline $\begin{array}{l}\text { Abnormal } \\
\text { echocardiogram }\end{array}$ & Yes & No & No & No & Yes & No & Yes & $42.9 \%$ \\
\hline Abnormal EKG & $\begin{array}{l}\text { Low voltage in } \\
\text { limb leads }\end{array}$ & $\begin{array}{l}\text { Not } \\
\text { done }\end{array}$ & $\begin{array}{l}\text { Not } \\
\text { done }\end{array}$ & $\begin{array}{l}\text { Initial ECG } \\
\text { RBBB }\end{array}$ & No & No & $\begin{array}{l}\text { Deep } Q \text { wave in } \\
\text { inferior leads }\end{array}$ & $42.9 \%$ \\
\hline $\begin{array}{l}\text { LAD/RCA z-score } \geq \\
2.5\end{array}$ & No & No & No & No & No & No & *Yes & $14.3 \%$ \\
\hline Pericardial Effusion & Minimal & No & No & No & No & No & No & $14.3 \%$ \\
\hline \multirow[t]{2}{*}{ Ejection Fraction } & $51 \%$ & $65 \%$ & $68 \%$ & $65 \%$ & $54 \%$ & $69 \%$ & $70 \%$ & $\begin{array}{l}28.6 \% \text { below } \\
\text { range }\end{array}$ \\
\hline & & & & & & & & (Ref: $<55 \%)$ \\
\hline $\begin{array}{l}\text { Mitral valve } \\
\text { regurgitation }\end{array}$ & Mild & No & Trivial & No & Mild & No & No & $42.9 \%$ \\
\hline Abnormal CXR & Yes & Yes & Yes & Yes & Yes & $\begin{array}{l}\text { Not } \\
\text { done }\end{array}$ & Yes & $\begin{array}{l}6 / 6,100 \% \\
\text { abnormal }\end{array}$ \\
\hline Pleural effusion & Small bilateral & No & No & No & $\begin{array}{l}\text { Small right } \\
\text { sided }\end{array}$ & No & No & $28.6 \%$ \\
\hline $\begin{array}{l}\text { Mechanical } \\
\text { ventilation }\end{array}$ & None & None & None & Yes & None & None & None & $14.3 \%$ \\
\hline $\begin{array}{l}\text { Abnormal US } \\
\text { abdomen }\end{array}$ & Yes & Yes & Yes & No & Yes & $\begin{array}{l}\text { Not } \\
\text { done }\end{array}$ & Yes & $\begin{array}{l}5 / 6,83.3 \% \\
\text { abnormal }\end{array}$ \\
\hline \multicolumn{9}{|c|}{ CXR, Chest X-ray; US, ultrasound } \\
\hline
\end{tabular}

Echocardiograms were performed on all patients at diagnosis with at least 4 weeks of follow-up, and after 8 weeks or earlier for patients with abnormal findings (Table 3). Cardiovascular involvement was seen in 3 of 7 patients in our study group (42.9\%). Two patients had transient ventricular dysfunction with ejection fraction $(\mathrm{EF})<55 \%$. Five patients $(71.4 \%)$ received vasoactive support. All patients had elevated levels of $\mathrm{N}$ terminal B-type natriuretic peptide (NT-proBNP) and troponin (Table 2). None of our cases had arrhythmias even in the acute stage. Coronaryartery aneurysms identified on the basis of a z score of 2.5 or higher in the left anterior descending (LAD) or right coronary artery (RCA) was seen in one patient (Table 3; Case-7) who developed a giant aneurysm in the left anterior descending (LAD) coronary artery (initially 4.9 mm, z-score > 10). This patient also had a dilated left main coronary artery measuring $3.9 \mathrm{~mm}(\mathrm{z}$-score +3.7$)$ and a dilated right coronary artery measuring $2.6 \mathrm{~mm}(z$-score + 2.7). The patient was placed on anticoagulation and dual antiplatelet therapy in addition to two doses of intravenous immunoglobulin (IVIG) and interleukin-1 (IL-1) inhibitor (anakinra). His LAD aneurysm enlarged to $9.5 \mathrm{~mm}$ z-score +31.4 and was still present on the latest follow-up after 8 weeks from diagnosis. 
The mean hospital stay of our MIS-C patients was 12.9 days, with 5 initially requiring intensive care management for ionotropic support (Table 3). Only one case (Case-4; Table 3) presented with acute respiratory distress syndrome (ARDS) and required mechanical ventilation. This patient also had prolonged fever and required 2 doses of IVIG, pulse steroids, and anakinra after no response to the initial measures. Broad spectrum antibiotics were initiated in all of the cases after consultation with the infectious disease team (Table 4). Aspirin was given to all patients during their hospital stay and on discharge for coronary thrombosis prophylaxis. All of our patients recovered and were discharged from the hospital in good clinical condition.

Table 4

Treatment

\begin{tabular}{|c|c|c|c|c|c|c|c|c|}
\hline & Case-1 & Case-2 & Case-3 & Case-4 & Case-5 & Case- 6 & Case-7 & Summary \\
\hline IVIG & Yes & Yes & Yes & Yes & Yes & Yes & Yes & $100 \%$ \\
\hline Corticosteroids & Yes & Yes & No & Yes & Yes & Yes & Yes & $85.7 \%$ \\
\hline Antibiotics & $\begin{array}{l}\text { Augmentin, } \\
\text { meropenem, } \\
\text { vancomycin } \\
\text { and } \\
\text { ceftriaxone }\end{array}$ & $\begin{array}{l}\text { Ceftriaxone } \\
\text { and } \\
\text { clindamycin }\end{array}$ & Ceftriaxone & $\begin{array}{l}\text { Ceftriaxone } \\
\text { and } \\
\text { meropenem }\end{array}$ & $\begin{array}{l}\text { Piperacillin/ } \\
\text { tazobactam } \\
\text { and } \\
\text { meropenem }\end{array}$ & Ceftriaxone & Ceftriaxone & $100 \%$ \\
\hline Anticoagulants & Enoxaparin & Enoxaparin & No & Enoxaparin & Enoxaparin & Enoxaparin & Enoxaparin & $85.7 \%$ \\
\hline $\begin{array}{l}\text { Epinephrine/ } \\
\text { norepinephrine }\end{array}$ & Yes & Yes & No & No & No & Yes & No & $42.9 \%$ \\
\hline Aspirin & Yes & Yes & Yes & Yes & Yes & Yes & Yes & $100 \%$ \\
\hline $\begin{array}{l}\text { Interleukin-1ra } \\
\text { inhibitor }\end{array}$ & No & No & No & Yes & No & No & Yes & $28.6 \%$ \\
\hline
\end{tabular}

\section{Discussion}

This case series describes 7 cases of MIS-C in our hospital. Similar to earlier reports, all patients were previously healthy and presented at our hospital approximately 4-6 weeks after the peak of the COVID-19 outbreak in the country.[4] In most cases, MIS-C was suspected early because of a history of COVID-19 infection based on RT-qPCR. All patients who were tested for COVID-19 antibody were also positive. In two cases who were initially negative by PCR, antibody testing was useful to determine the COVID-19 infection status of the suspected MIS-C patients. Overall, $71.4 \%$ of our patients had positive COVID-19 PCR results as compared to $~ 50 \%$ of positive COVID-19 PCR results reported in other studies.[10, 11]

The clinical presentations of MIS-C patients in this case series were mostly similar to earlier reports with fever and gastrointestinal problems being the most common initial symptoms.[11, 12] In our experience, abdominal pain in these patients was severe in nature and resembled appendicitis. In fact, one of our patients underwent appendectomy, which subsequently showed a normal appendix. Respiratory symptoms were less prominent in our cohort with only one case having cough and another being intubated as part of ionotropic support without significant lung pathology. This is consistent with previous studies although some studies have reported a higher percentage of cases requiring respiratory support during their illness.[10, 12, 13]

Significant cardiac involvement in cases of MIS-C has been documented in recent reports highlighting the common similarity with KD. This emphasizes the need for cardiac evaluation with echocardiography at diagnosis and at regular intervals consistent with the management of KD. $[4,14]$ It is reported that up to $56 \%$ of cases can have decreased systolic ventricular function with EF $<55 \%$, the most common cardiac abnormality seen in these patients,[12,14] which in contrast to KD has less propensity for significant ventricular dysfunction.[13] In our small case series, although approximately three quarter of patients required vasopressor support, only two had transient LV dysfunction that recovered within a short period, which is in contrast with patients with KD who rarely present with hemodynamic instability.[4]

Elevated troponin levels have been previously associated with poor outcome in patients with COVID-19 and could be a reflection of the degree of systemic inflammation and myocardial effects.[15] Elevated troponin, NT-proBNP and D-dimer levels were also commonly noted in our case series (Table 2). Of particular interest is the degree of coronary artery involvement in MIS-C cases which occurred in one case with the patient developing a giant aneurysm in the LAD and dilatation of both the left main and right coronary arteries. Coronary artery involvement in MIS-C cases is reported to occur in up to $15 \%$ of cases in a recent report with few patients developing giant aneurysms.[11, 13, 14, 16] Although the true incidence of such involvement is still to be defined, it seems similar to that in KD where it occurs in about $25 \%$ and $4 \%$ of untreated and treated 
patients, respectively.[17] In addition, no clear predisposing factors were identified for those with higher risk for development of coronary involvement in MIS-C cases.

Previous studies showed a death rate of around 1.7-1.8\%.[12, 18] Fortunately, all of the cases in our case series had a favorable outcome, with no deaths. With the exception of two cases, all patients in our case series initially required PICU care with inotropic support being the main reason for PICU admission, consistent with previous reports of MIS-C.[4, 10, 12, 19] The majority of our cases responded well to IVIG with or without intravenous (IV) corticosteroids in terms of subsidence of fever and decreased need for inotropic support. Only two cases required two doses of IVIG and IL-1 inhibitor, as these patients had a more complicated course with ARDS and coronary aneurysm, respectively. These patients also had prolonged fever, which did not respond to initial measures. A similar pattern in clinical response was noted in less than $10 \%$ of cases requiring IL-1 or IL-6 antagonists in a recent systematic review [12]. Due to the similarities between MIS-C and KD and their cardiac involvement, current treatment strategies are similar from cardiac point of view.[4, 12] However, the long-term outcomes of MIS-C, such as the sequelae of coronary artery aneurysm formation, remain unknown. The benefit of longer-term cardiac follow up to evaluate the effects on cardiac function and persistence or regression of coronary aneurysms remain to be determined.

\section{Conclusions}

We report the first case series of COVID-19 associated MIS-C in Qatar. Our patients commonly presented with fever, rash and gastrointestinal symptoms and required intensive care. Most common laboratory findings include lymphopenia and thrombocytopenia and elevated CRP, ferritin, PCT, D-dimers, PT, NT-proBNP and troponin. Only one patient had acute respiratory distress syndrome (ARDS) and required respiratory support, and cardiovascular involvement was observed in approximately $43 \%$ of patients, with one patient with coronary-artery aneurysms. All patients were treated with IVIG, and some received corticosteroids and IL-1 inhibitors; all patients were fully recovered.

\section{Abbreviations}

COVID-19: coronavirus disease 2019

MIS-C: multisystem inflammatory syndrome in children

WHO: World Health Organization

IL-1: interleukin - 1

SARS-CoV-2: severe acute respiratory syndrome coronavirus 2

KD: Kawasaki disease

RT-qPCR: reverse transcriptase - quantitative real time polymerase chain reaction

PICU: pediatric intensive care unit

URTI: upper respiratory tract infection

UTI: urinary tract infection

NPW: nasopharyngeal wash

WBC: white blood cell

CRP: C-reactive protein

PCT: procalcitonin

IL-6: interleukin - 6

US: ultrasound

EF: ejection fraction

NT-proBNP: N-terminal B-type natriuretic peptide

LAD: left anterior descending 
RCA: right coronary artery

ARDS: acute respiratory distress syndrome

IVIG: intravenous immunoglobulin

IV: intravenous

\section{Declarations}

Ethics approval and consent to participate: Ethics approval for the study and a waiver of informed consent was obtained from the Institutional Review Board of Sidra Medicine. All methods were carried out in accordance with relevant guidelines and regulations.

Consent for publication: Not applicable

Competing interests: The authors declare that they have no competing interests.

Funding : No funding was received for this study.

Author contributions: M.R.H conceptualized and designed the study and performed data analysis. M.R.H and K.A.Z., reviewed patient charts and collected data. M.R.H., K.A.Z., K.D. and Y.H drafted the manuscript. All other authors participated in the critical review of the final manuscript.

Acknowledgments: The authors thank all staff members in Sidra Medicine, Qatar who were involved in the clinical care of the subjects of the study,

\section{References}

1. Coronavirus disease 2019 (COVID-19): Clinical features [https://www.uptodate.com/contents/coronavirus-disease-2019-covid-19-clinicalfeatures?topicRef=126981\&source=see_link]

2. Coronavirus disease 2019 (COVID-19): Multisystem inflammatory syndrome in children (MIS-C) clinical features, evaluation, and diagnosis [https://www.uptodate.com/contents/coronavirus-disease-2019-covid-19-multisystem-inflammatory-syndrome-in-children-mis-c-clinicalfeatures-evaluation-and-diagnosis?topicRef=129614\&source=see_link]

3. Multisystem Inflammatory Syndrome (MIS-C) [https://www.cdc.gov/coronavirus/2019-ncov/daily-life-coping/children/mis-c.html]

4. Feldstein LR, Rose EB, Horwitz SM, Collins JP, Newhams MM, Son MBF, Newburger JW, Kleinman LC, Heidemann SM, Martin AA et al: Multisystem Inflammatory Syndrome in U.S. Children and Adolescents. N Engl J Med 2020, 383(4):334-346.

5. Dufort EM, Koumans EH, Chow EJ, Rosenthal EM, Muse A, Rowlands J, Barranco MA, Maxted AM, Rosenberg ES, Easton D et al: Multisystem Inflammatory Syndrome in Children in New York State. N Engl J Med 2020, 383(4):347-358.

6. Davies P, Evans C, Kanthimathinathan HK, Lillie J, Brierley J, Waters G, Johnson M, Griffiths B, du Pre P, Mohammad Z et al: Intensive care admissions of children with paediatric inflammatory multisystem syndrome temporally associated with SARS-CoV-2 (PIMS-TS) in the UK: a multicentre observational study. Lancet Child Adolesc Health 2020, 4(9):669-677.

7. Mamishi S, Movahedi Z, Mohammadi M, Ziaee V, Khodabandeh M, Abdolsalehi MR, Navaeian A, Heydari H, Mahmoudi S, Pourakbari B: Multisystem inflammatory syndrome associated with SARS-CoV-2 infection in $\mathbf{4 5}$ children: a first report from Iran. Epidemiol Infect 2020 , 148:e196.

8. Al Ameer HH, AlKadhem SM, Busaleh F, AlKhwaitm S, Llaguno MBB: Multisystem Inflammatory Syndrome in Children Temporally Related to COVID-19: A Case Report From Saudi Arabia. Cureus 2020, 12(9):e10589.

9. Almoosa ZA, Al Ameer HH, AlKadhem SM, Busaleh F, AlMuhanna FA, Kattih O: Multisystem Inflammatory Syndrome in Children, the Real Disease of COVID-19 in Pediatrics - A Multicenter Case Series From Al-Ahsa, Saudi Arabia. Cureus 2020, $12(10):$ :e11064.

10. Torres JP, Izquierdo G, Acuna M, Pavez D, Reyes F, Fritis A, Gonzalez R, Rivacoba C, Contardo V, Tapia LI: Multisystem inflammatory syndrome in children (MIS-C): Report of the clinical and epidemiological characteristics of cases in Santiago de Chile during the SARS-CoV2 pandemic. Int $J$ Infect Dis 2020, 100:75-81.

11. Kaushik A, Gupta S, Sood M, Sharma S, Verma S: A Systematic Review of Multisystem Inflammatory Syndrome in Children Associated With SARS-CoV-2 Infection. Pediatr Infect Dis J 2020, 39(11):e340-e346.

12. Ahmed M, Advani S, Moreira A, Zoretic S, Martinez J, Chorath K, Acosta S, Naqvi R, Burmeister-Morton F, Burmeister F et al: Multisystem inflammatory syndrome in children: A systematic review. EClinicalMedicine 2020, 26:100527.

13. Whittaker E, Bamford A, Kenny J, Kaforou M, Jones CE, Shah P, Ramnarayan P, Fraisse A, Miller O, Davies P et al: Clinical Characteristics of 58 Children With a Pediatric Inflammatory Multisystem Syndrome Temporally Associated With SARS-CoV-2. JAMA 2020, 324(3):259-269. 
14. Loke $\mathrm{YH}, \mathrm{Berul} \mathrm{Cl}$, Harahsheh AS: Multisystem inflammatory syndrome in children: Is there a linkage to Kawasaki disease? Trends Cardiovasc Med 2020, 30(7):389-396.

15. Nguyen Y, Corre F, Honsel V, Curac S, Zarrouk V, Burtz CP, Weiss E, Moyer JD, Gauss T, Gregory J et al: A nomogram to predict the risk of unfavourable outcome in COVID-19: a retrospective cohort of 279 hospitalized patients in Paris area. Ann Med 2020, 52(7):367-375.

16. Cheung EW, Zachariah P, Gorelik M, Boneparth A, Kernie SG, Orange JS, Milner JD: Multisystem Inflammatory Syndrome Related to CoVID19 in Previously Healthy Children and Adolescents in New York City. JAMA 2020, 324(3):294-296.

17. McCrindle BW, Rowley AH, Newburger JW, Burns JC, Bolger AF, Gewitz M, Baker AL, Jackson MA, Takahashi M, Shah PB et al: Diagnosis, Treatment, and Long-Term Management of Kawasaki Disease: A Scientific Statement for Health Professionals From the American Heart Association. Circulation 2017, 135(17):e927-e999.

18. Godfred-Cato S, Bryant B, Leung J, Oster ME, Conklin L, Abrams J, Roguski K, Wallace B, Prezzato E, Koumans EH et al: CoVID-19Associated Multisystem Inflammatory Syndrome in Children - United States, March-July 2020. MMWR Morb Mortal Wkly Rep 2020, 69(32):1074-1080.

19. Toubiana J, Poirault C, Corsia A, Bajolle F, Fourgeaud J, Angoulvant F, Debray A, Basmaci R, Salvador E, Biscardi S et al: Kawasaki-like multisystem inflammatory syndrome in children during the covid-19 pandemic in Paris, France: prospective observational study. BMJ 2020 , 369:m2094.

\section{Tables}

Table 1: Patient characteristics and clinical presentation

\begin{tabular}{|c|c|c|c|c|c|c|c|c|}
\hline & Case-1 & Case-2 & Case-3 & Case-4 & Case-5 & Case-6 & Case-7 & Summary \\
\hline \multicolumn{9}{|l|}{ Demographics } \\
\hline Age & 6 & 6 & 3 & 7 & 7 & 9 & 1 & Mean, $5.6 \pm 2.7$ \\
\hline Gender & Male & Male & Male & Male & Female & Female & Male & Male, $71.4 \%$ \\
\hline \multicolumn{9}{|l|}{ Clinical presentation } \\
\hline Fever & Yes & Yes & Yes & Yes & Yes & Yes & Yes & $100 \%$ \\
\hline Rash & No & Yes & Yes & Yes & Yes & Yes & Yes & $85.7 \%$ \\
\hline Tachycardia & Yes & No & Yes & Yes & No & Yes & Yes & $71.4 \%$ \\
\hline Tachypnea & No & Yes & No & No & Yes & No & No & $28.6 \%$ \\
\hline Hypotension & Yes & Yes & No & Yes & No & No & No & $42.9 \%$ \\
\hline Abdominal pain & Yes & No & Yes & *Yes & Yes & Yes & No & $71.4 \%$ \\
\hline Diarrhea & No & No & Yes & No & No & Yes & Yes & $42.9 \%$ \\
\hline Vomiting & Yes & Yes & Yes & Yes & Yes & Yes & Yes & $100 \%$ \\
\hline Decreased oral intake & Yes & Yes & Yes & No & No & No & Yes & $57.1 \%$ \\
\hline Cough & Yes & No & No & No & No & No & No & $14.3 \%$ \\
\hline Sore throat & No & Yes & No & No & No & No & No & $14.3 \%$ \\
\hline Conjunctivitis & No & Yes & No & Yes & No & Yes & Yes & $57.1 \%$ \\
\hline
\end{tabular}

*Patient underwent laparoscopic appendectomy

Table 2: Laboratory results 


\begin{tabular}{|c|c|c|c|c|c|c|c|c|}
\hline & Case-1 & Case-2 & Case-3 & Case-4 & Case-5 & Case-6 & Case-7 & Summary \\
\hline \multicolumn{9}{|l|}{ COVID-19 } \\
\hline RT-qPCR & $\begin{array}{c}\text { NPS- } \\
\text { Neg } \\
\text { NPW- } \\
\text { Pos }\end{array}$ & $\begin{array}{c}\text { NPS- } \\
\text { Neg } \\
\text { NPW- } \\
\text { Pos }\end{array}$ & $\begin{array}{l}\text { NPS- } \\
\text { Pos }\end{array}$ & $\begin{array}{l}\text { NPS- } \\
\text { Neg }\end{array}$ & $\begin{array}{l}\text { *NPS- } \\
\text { Pos }\end{array}$ & $\begin{array}{l}\text { *NPS- } \\
\text { Pos }\end{array}$ & $\begin{array}{l}\text { NPS- } \\
\text { Neg }\end{array}$ & $\begin{array}{c}71.4 \% \text { cases positive in at least one } \\
\text { specimen }\end{array}$ \\
\hline Serology & Positive & Positive & Positive & Positive & $\begin{array}{l}\text { Not } \\
\text { done }\end{array}$ & Positive & Positive & $6 / 6,100 \%$ positive \\
\hline \multicolumn{9}{|l|}{ Hematology } \\
\hline $\operatorname{WBC}\left(10^{9} / \mathrm{L}\right)$ & 27.3 & 19.4 & 16 & 9.7 & 16.9 & 6.9 & 24.1 & $\begin{array}{c}\text { 71.4\% above range } \\
\text { (Ref: } 4-14 \text { ) }\end{array}$ \\
\hline $\begin{array}{l}\text { Neutrophil } \\
\left(10^{9} / \mathrm{L}\right)\end{array}$ & 24.4 & 16.5 & 5.3 & 9.5 & 13.9 & 4.6 & 16.1 & $\begin{array}{l}\text { 71.4\% above range } \\
\text { (Ref: } 0.8-7.2 \text { ) }\end{array}$ \\
\hline $\begin{array}{l}\text { Lymphocyte } \\
\left(10^{9} / \mathrm{L}\right)\end{array}$ & 0.9 & 0.8 & 1.2 & 0.2 & 2.1 & 0.6 & 6.5 & $\begin{array}{l}\text { 71.4\% below range } \\
\text { (Ref: } 1.3-8 \text { ) }\end{array}$ \\
\hline $\begin{array}{l}\text { Platelets } \\
\left(10^{3} / \mathrm{mL}\right) \\
\end{array}$ & 140 & 80 & 570 & 105 & 116 & 105 & 900 & $\begin{array}{l}\text { 71.4\% below range } \\
\text { (Ref: } 150-400 \text { ) }\end{array}$ \\
\hline \multicolumn{9}{|c|}{ Inflammatory markers } \\
\hline $\mathrm{CRP}(\mathrm{mg} / \mathrm{L})$ & 262.2 & 228.3 & 162 & 304.5 & 93 & 82.8 & 143 & $\begin{array}{l}\text { 100\% above range } \\
\text { (Ref: } 0-7.5 \text { ) }\end{array}$ \\
\hline Ferritin (ng/mL) & 324 & 581 & 377 & 334 & 326 & 341 & 621 & $\begin{array}{c}\text { 100\% above range } \\
\text { (Ref: } 10-56 \text { ) }\end{array}$ \\
\hline PCT (ng/mL) & 21.6 & 7.22 & 9.4 & $>50$ & 2.15 & $\begin{array}{l}\text { Not } \\
\text { done }\end{array}$ & 0.59 & $\begin{array}{c}6 / 6,100 \% \text { above range } \\
\text { (Ref: <0.1) }\end{array}$ \\
\hline IL-6 $(\mathrm{pg} / \mathrm{mL})$ & 35 & 4 & $\begin{array}{l}\text { Not } \\
\text { done }\end{array}$ & $\begin{array}{l}\text { Not } \\
\text { done }\end{array}$ & 2665 & $\begin{array}{l}\text { Not } \\
\text { done }\end{array}$ & 100 & $\begin{array}{l}\text { 3/4 above range } \\
\text { (Ref: } 0-16.4 \text { ) }\end{array}$ \\
\hline \multicolumn{9}{|l|}{ Coagulation } \\
\hline PT (sec) & 16.8 & 15.1 & 18.3 & 17 & 17.5 & 15.9 & 12 & $\begin{array}{l}\text { 83\% above range } \\
\text { (Ref: } 11.7-15.1 \text { ) }\end{array}$ \\
\hline D-dimer (mg/L) & 7440 & 2266 & 7500 & $>7500$ & 3538 & 2381 & 3060 & $\begin{array}{l}\text { 100\% above range } \\
\text { (Ref: £500) }\end{array}$ \\
\hline $\begin{array}{l}\text { Fibrinogen } \\
(\mathrm{mg} / \mathrm{dL})\end{array}$ & 4 & 3.9 & 3.4 & 4.4 & 3.7 & 3.6 & 4.3 & $\begin{array}{l}\text { 28.6\% above range } \\
\text { (Ref: } 1.6-4 \text { ) }\end{array}$ \\
\hline \multicolumn{9}{|l|}{ Cardiac } \\
\hline Troponin (ng/L) & 40 & 14 & 68 & 309 & 161 & 34 & 4 & $\begin{array}{l}\text { 100\% above range } \\
\text { (Ref: } 0-0.4 \text { ) }\end{array}$ \\
\hline $\begin{array}{l}\text { NT-proBNP } \\
\text { (ng/L) }\end{array}$ & 5253 & 7006 & 2314 & 2874 & 592 & 506 & 1444 & $\begin{array}{l}\text { 100\% above range } \\
\text { (Ref: < 125) }\end{array}$ \\
\hline
\end{tabular}

NPS, nasopharyngeal swab; NPW, nasopharyngeal wash; WBC, white blood cell; CRP, C-reactive protein; PCT, procalcitonin; PT, prothrombin time; NT-proBNP, N-terminal B-type natriuretic peptide

*Previous positive

Table 3: Clinical outcome 


\begin{tabular}{|c|c|c|c|c|c|c|c|c|}
\hline & Case-1 & $\begin{array}{c}\text { Case- } \\
2\end{array}$ & $\begin{array}{c}\text { Case- } \\
3\end{array}$ & Case-4 & Case-5 & $\begin{array}{c}\text { Case- } \\
6\end{array}$ & Case-7 & Summary \\
\hline $\begin{array}{l}\text { Hospital length of } \\
\text { stay (days) }\end{array}$ & 12 & 10 & 6 & 20 & 7 & 8 & 27 & $\begin{array}{c}\text { Mean, } \\
12.9 \pm 7.8\end{array}$ \\
\hline ICU stay (days) & 12 & 10 & None & 11 & 4 & 3 & None & $71.4 \%$ \\
\hline Shock & Yes & Yes & None & Yes & None & Yes & None & $57.1 \%$ \\
\hline $\begin{array}{l}\text { Abnormal } \\
\text { echocardiogram }\end{array}$ & Yes & No & No & No & Yes & No & Yes & $42.9 \%$ \\
\hline Abnormal EKG & $\begin{array}{l}\text { Low voltage in } \\
\text { limb leads }\end{array}$ & $\begin{array}{l}\text { Not } \\
\text { done }\end{array}$ & $\begin{array}{l}\text { Not } \\
\text { done }\end{array}$ & $\begin{array}{c}\text { Initial ECG } \\
\text { RBBB }\end{array}$ & No & No & $\begin{array}{l}\text { Deep Q wave in } \\
\text { inferior leads }\end{array}$ & $42.9 \%$ \\
\hline $\begin{array}{l}\text { LAD/RCA z-score } \\
\geq 2.5\end{array}$ & No & No & No & No & No & No & *Yes & $14.3 \%$ \\
\hline $\begin{array}{l}\text { Pericardial } \\
\text { Effusion }\end{array}$ & Minimal & No & No & No & No & No & No & $14.3 \%$ \\
\hline Ejection Fraction & $51 \%$ & $65 \%$ & $68 \%$ & $65 \%$ & $54 \%$ & $69 \%$ & $70 \%$ & $\begin{array}{c}28.6 \% \text { below } \\
\text { range } \\
\text { (Ref: }<55 \%)\end{array}$ \\
\hline $\begin{array}{l}\text { Mitral valve } \\
\text { regurgitation }\end{array}$ & Mild & No & Trivial & No & Mild & No & No & $42.9 \%$ \\
\hline Abnormal CXR & Yes & Yes & Yes & Yes & Yes & $\begin{array}{l}\text { Not } \\
\text { done }\end{array}$ & Yes & $\begin{array}{l}6 / 6,100 \% \\
\text { abnormal }\end{array}$ \\
\hline Pleural effusion & Small bilateral & No & No & No & $\begin{array}{c}\text { Small } \\
\text { right sided }\end{array}$ & No & No & $28.6 \%$ \\
\hline $\begin{array}{l}\text { Mechanical } \\
\text { ventilation }\end{array}$ & None & None & None & Yes & None & None & None & $14.3 \%$ \\
\hline $\begin{array}{l}\text { Abnormal US } \\
\text { abdomen }\end{array}$ & Yes & Yes & Yes & No & Yes & $\begin{array}{l}\text { Not } \\
\text { done }\end{array}$ & Yes & $\begin{array}{l}5 / 6,83.3 \% \\
\text { abnormal }\end{array}$ \\
\hline
\end{tabular}

CXR, Chest X-ray; US, ultrasound

*LAD large aneurysm $9.5 \mathrm{~mm}$ (Z score + 31.44), RCA small aneurysm $3.1 \mathrm{~mm}$ (Z score +4.16), LMCA medium aneurysm 5.2 $\mathrm{mm}$ Z score +7.75

Table 4: Treatment

\begin{tabular}{|c|c|c|c|c|c|c|c|c|}
\hline & Case-1 & Case-2 & Case-3 & Case-4 & Case-5 & Case-6 & Case-7 & Summary \\
\hline IVIG & Yes & Yes & Yes & Yes & Yes & Yes & Yes & $100 \%$ \\
\hline Corticosteroids & Yes & Yes & No & Yes & Yes & Yes & Yes & $85.7 \%$ \\
\hline Antibiotics & $\begin{array}{c}\text { Augmentin, } \\
\text { meropenem, } \\
\text { vancomycin } \\
\text { and } \\
\text { ceftriaxone }\end{array}$ & $\begin{array}{l}\text { Ceftriaxone } \\
\text { and } \\
\text { clindamycin }\end{array}$ & Ceftriaxone & $\begin{array}{l}\text { Ceftriaxone } \\
\text { and } \\
\text { meropenem }\end{array}$ & $\begin{array}{l}\text { Piperacillin/ } \\
\text { tazobactam } \\
\text { and } \\
\text { meropenem }\end{array}$ & Ceftriaxone & Ceftriaxone & $100 \%$ \\
\hline Anticoagulants & Enoxaparin & Enoxaparin & No & Enoxaparin & Enoxaparin & Enoxaparin & Enoxaparin & $85.7 \%$ \\
\hline $\begin{array}{l}\text { Epinephrine/ } \\
\text { norepinephrine }\end{array}$ & Yes & Yes & No & No & No & Yes & No & $42.9 \%$ \\
\hline Aspirin & Yes & Yes & Yes & Yes & Yes & Yes & Yes & $100 \%$ \\
\hline $\begin{array}{l}\text { Interleukin-1ra } \\
\text { inhibitor }\end{array}$ & No & No & No & Yes & No & No & Yes & $28.6 \%$ \\
\hline
\end{tabular}

IVIG, intravenous immunoglobulin 